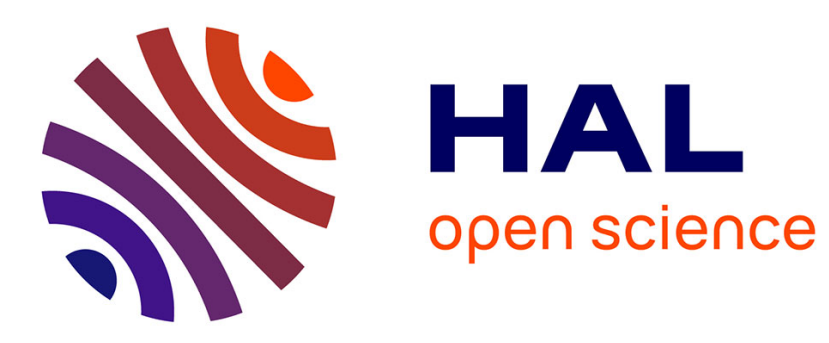

\title{
Hydrophobic Covalent Patterns on Cellulose Paper through Photothiol-X Ligations
}

Guillaume Bretel, Jordi Rull-Barrull, Medy Nongbe, Jean-Philippe Terrier, Erwan Le Grognec, Francois-Xavier Felpin

\section{- To cite this version:}

Guillaume Bretel, Jordi Rull-Barrull, Medy Nongbe, Jean-Philippe Terrier, Erwan Le Grognec, et al.. Hydrophobic Covalent Patterns on Cellulose Paper through Photothiol-X Ligations. ACS Omega, 2018, 3 (8), pp.9155-9159. 10.1021/acsomega.8b01317 . hal-02054026

\section{HAL Id: hal-02054026 \\ https://hal.science/hal-02054026}

Submitted on 1 Mar 2019

HAL is a multi-disciplinary open access archive for the deposit and dissemination of scientific research documents, whether they are published or not. The documents may come from teaching and research institutions in France or abroad, or from public or private research centers.
L'archive ouverte pluridisciplinaire HAL, est destinée au dépôt et à la diffusion de documents scientifiques de niveau recherche, publiés ou non, émanant des établissements d'enseignement et de recherche français ou étrangers, des laboratoires publics ou privés. 


\title{
Hydrophobic Covalent Patterns on Cellulose Paper through Photothiol-X Ligations
}

\author{
Guillaume Bretel, ${ }^{\dagger}$ Jordi Rull-Barrull, ${ }^{\dagger}$ Medy C. Nongbe, ${ }^{\dagger}$ Jean-Philippe Terrier, ${ }^{\dagger}$ Erwan Le Grognec, ${ }^{\dagger}$ (1) \\ and François-Xavier Felpin*, ${ }^{\dagger}, \S \odot$ \\ ${ }^{\dagger}$ Université de Nantes, UFR des Sciences et des Techniques, CNRS UMR 6230, CEISAM, 2 rue de la Houssinière, 44322 Nantes \\ Cedex 3, France \\ ${ }^{\ddagger}$ Université de Nantes, IFSTTAR, MAST, Route de Bouaye, 44344 Bouguenais Cedex, France \\ ${ }^{\S}$ Institut Universitaire de France, 1 rue Descartes, 75231 Paris Cedex 05, France
}

Supporting Information

ABSTRACT: In the current study, we introduce photothiol$\mathrm{X}$ chemistry as a powerful method to create hydrophobic patterns covalently grafted to the surface of cellulose paper. The general strategy builds on the use of a cellulose-based molecular printboard featuring disulfide functions which upon spatiocontrolled light irradiation at $365 \mathrm{~nm}$ allows robust photothiol-X ligations with hydrophobic moieties. A screening of structurally diverse molecular architectures as hydrophobic coating was conducted, and the most impressive result obtained with cholesterol moieties allows the creation of spatially well-resolved hydrophobic patterns with a contact angle of $140.8^{\circ}$. Our discoveries are supported by in-depth characterization studies using Fourier transform infrared spectroscopy, X-ray photoelectron spectrometry, and scanning electron microscopy analyses.

\section{INTRODUCTION}

Cellulose is one of the most promising renewable feedstock from biomass with an almost inexhaustible annual bioproduction of $10^{11}$ to $10^{12}$ tons. ${ }^{1}$ Natural fibers of cellulose possess many interesting properties such as good mechanical strength, renewability, biodegradability and nontoxicity. As a result, the value of cellulose is recognized for many usages, for instance, as a raw material in wood or textile fibers or as a pure polymer used as additive in materials, agrifood products, cosmetics, pharmaceuticals, and so on. ${ }^{2,3}$ In addition to the use of chemically unaltered cellulose chains, the search for new artificial cellulose-based materials prepared by chemical modification of glucose units is an attractive field of research., ${ }^{4,5}$ One of the main objectives of the latter consists of either altering the physical properties of native cellulose or preparing functional cellulose-based materials. ${ }^{6,7}$

Cellulose-based materials have a high tendency to water and moisture absorption because of the high hydrophilicity of cellulose fibers. Although the hydrophilic properties of cellulose can be of great value for specific uses, it creates acute problems when the mechanical strength and physical integrity of cellulose-based materials exposed to humidity or water are altered. This issue is particularly salient with paper materials used for packaging and printing purposes. The hydrophobization of cellulose paper is an attractive opportunity to combine the benefits of natural fibers with high water resistance and repellent properties. Traditional approaches essentially focused on the hydrophobization of cellulose paper through either noncovalent ${ }^{8-16}$ or covalent coatings, ${ }^{17-23}$ without any spatial control. Controlling hydrophobic zones on cellulose paper through spatially controlled coatings is of much broader interest because it allows to create hydrophobic writing, ${ }^{24}$ microfluidic devices, ${ }^{25}$ or even platforms for parallel synthesis. ${ }^{26}$ Methods developed for creating hydrophobic patterns on cellulose paper include the use of wax, ${ }^{27}$ poly(dimethylsiloxane) ${ }^{28}$ methylsilesquioxane, ${ }^{29}$ plasma treatment, ${ }^{30}$ photolithography with SU-8 photoresist, $^{31}$ and Teflon. ${ }^{26}$ All of these methods involve the impregnation of the hydrophobic patterns inside the porous structure of cellulose paper but without chemical bonds with glucose units. By contrast, creating more robust hydrophobic patterns covalently bound to the cellulose surface remains a much less-explored strategy, likely because available synthetic tools allowing a spatial control of hydrophobization are scarce. In pioneering studies, Barner-Kowollik et al. designed a spatially defined polymer grafting through a nitrile imine-mediated tetrazole-ene cycloaddition mediated by UV light. ${ }^{32}$ Rojas, Levkin et al. reported spatially controlled thiol-ene ${ }^{33}$ and thiol-yne ${ }^{34}$ functionalization of nanocellulose films and paper with fluorinated alkyl chains. Although very high water contact angles were reached, up to $166^{\circ}$, the reactive film grafted with alkene or alkynes functions displayed an inherent hydrophobicity (up to $126^{\circ}$ ) prior to the patterning step, requiring

Received: June 12, 2018

Accepted: July 30, 2018

Published: August 15, 2018 
Table 1. Optimization for the Preparation of Cell-Dis

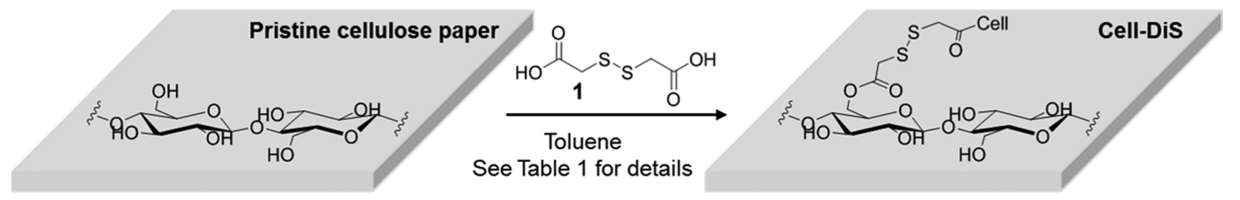

\begin{tabular}{|c|c|c|c|c|c|}
\hline entry & acid/loading (equiv) & dithiodiglycolic acid (equiv) & temperature $\left({ }^{\circ} \mathrm{C}\right)$ & time $(\mathrm{h})$ & $\operatorname{DS}(\%)^{a}$ \\
\hline 1 & PTSA/0.05 & 3 & 110 & 17 & 8 \\
\hline 2 & PTSA/0.1 & 3 & 110 & 17 & 13 \\
\hline 3 & PTSA/0.2 & 3 & 110 & 17 & $10^{b}$ \\
\hline 4 & PTSA/0.5 & 3 & 110 & 17 & $\mathrm{ND}^{c, d}$ \\
\hline 5 & $\mathrm{CSA} / 0.1$ & 3 & 110 & 17 & $14^{b}$ \\
\hline 6 & $\mathrm{BF}_{3} \cdot \mathrm{Et}_{2} \mathrm{O} / 0.1$ & 3 & 110 & 17 & 16 \\
\hline 7 & $\mathrm{BF}_{3} \cdot \mathrm{Et}_{2} \mathrm{O} / 0.1$ & 3 & 110 & 24 & 17 \\
\hline 8 & $\mathrm{BF}_{3} \cdot \mathrm{Et}_{2} \mathrm{O} / 0.2$ & 3 & 110 & 24 & $18^{b}$ \\
\hline 9 & $\mathrm{BF}_{3} \cdot \mathrm{Et}_{2} \mathrm{O} / 0.1$ & 1 & 110 & 24 & 13 \\
\hline 10 & $\mathrm{BF}_{3} \cdot \mathrm{Et}_{2} \mathrm{O} / 0.1$ & 5 & 110 & 24 & $17^{b}$ \\
\hline 11 & $\mathrm{BF}_{3} \cdot \mathrm{Et}_{2} \mathrm{O} / 0.1$ & 3 & 90 & 24 & 13 \\
\hline
\end{tabular}

${ }^{a}$ DS calculated by elemental analysis. ${ }^{b}$ Brown marks were occasionally observed. ${ }^{c}$ ND: not determined. ${ }^{d}$ The paper was stained on its whole surface.

further modifications to create distinct hydrophobic/hydrophilic zones.

In the frame-a-program devoted to the discovery of functional cellulose papers, ${ }^{35-38}$ we recently created a paperbased molecular printboard for spatiotemporal writing through photothiol-X ligations of either UV active or colored inks upon light irradiation. ${ }^{39}$ This powerful strategy displays a number of salient features such as a (i) facile ligation following the principles of click chemistry, (ii) spatiotemporal control, (iii) high molecular modularity, and (iv) whiteness preservation in nonpatterned regions. The objective of our current work is to demonstrate that the photothiol-X ligation strategy is a powerful approach for creating covalent hydrophobic patterns onto the surface of cellulose paper.

\section{RESULTS AND DISCUSSION}

The UV-mediated thiol-X ligation strategy stands on the use of a photoresponsive cellulose paper covalently grafted with dithiodiglycolic acid 1 (Cell-DiS). The disulfide bond is subjected to a homolytic cleavage into the corresponding thiyl radical upon light irradiation at $365 \mathrm{~nm}$ in the presence of 2,2dimethoxy-2-phenylacetophenone (DMPA) as a radical initiator. In a recent report, we discussed in-depth the benefits of using disulfide compounds as thiyl radical precursors instead of usual thiol functions because of the lower bond dissociation energy. ${ }^{18}$ In our previous studies, Cell-DiS was prepared by esterification of the pristine paper with dithiodiglycolic acid $\mathbf{1}$, using $p$-toluenesulfonic acid (PTSA) as a catalyst in refluxing toluene. However, we experienced difficulties for preserving the whiteness of Cell-DiS on the whole surface because crystals of PTSA, weakly soluble in toluene, were frequently adsorbed in the porous network of cellulose, staining the paper with brown marks. Therefore, we reinvestigated the esterification step with $\mathbf{1}$ following a careful multivariable optimization. The reaction efficiency was followed by elemental analysis, and background reactions were systematically performed without catalyst to confirm the absence of residual adsorbed diacid $\mathbf{1}$ (Table 1). We confirmed that PTSA was responsible for the brown marks frequently observed on Cell-DiS because an increase of PTSA loading from 0.1 to 0.2 equivalent exacerbated the staining (entries 2 vs 3 ), whereas a further increase to 0.5 equivalent completely burnt the paper (entry 4). Unfortunately, reducing the loading of PTSA to 0.05 equivalent indeed preserved the whiteness, but the esterification efficiency was significantly altered because the degree of substitution (DS) dropped to 8\% (entry 1). Switching PTSA for camphorsulfonic acid (CSA) did not improve the process because brown marks were again occasionally observed on the paper surface (entry 5). Because the brown marks frequently observed on Cell-DiS results from the low solubility of PTSA and CSA in toluene leading to an inhomogeneous dispersion, we envisaged the use of $\mathrm{BF}_{3} \cdot \mathrm{Et}_{2} \mathrm{O}$ as a liquid acid catalyst. With 0.1 equivalent of $\mathrm{BF}_{3} \cdot \mathrm{Et}_{2} \mathrm{O}$, the grafting of dithiodiglycolic acid 1 reached $16 \%$ after $17 \mathrm{~h}$ of stirring and $17 \%$ after $24 \mathrm{~h}$, without any staining issues (entries 6-7). We were unable to improve the process because higher loading of $\mathrm{BF}_{3} \cdot \mathrm{Et}_{2} \mathrm{O}$ significantly altered the paper whiteness (entry 8 ). Further variations of both the loading of compound $\mathbf{1}$ and the reaction temperature did not allow to improve the DS (entries 9-11).

In summary, the esterification of dithiodiglycolic acid was best performed with $\mathrm{BF}_{3} \cdot \mathrm{Et}_{2} \mathrm{O}$ as Lewis acid catalyst under refluxing toluene. The DS of $17 \%$ indicates that almost two hydroxyl groups were functionalized every 10 glucose units. This level of grafting appears to be the best compromise to allow further functionalization without compromising both the physical integrity and the native hydrophilicity of cellulose paper.

We complemented the characterization of Cell-DiS through Fourier transform infrared spectroscopy (FTIR), X-ray photoelectron spectrometry (XPS), and scanning electron microscopy (SEM). The creation of the ester linkage is evidenced on the FTIR spectrum by a new band at $1725 \mathrm{~cm}^{-1}$; the remaining bands between 400 and $1500 \mathrm{~cm}^{-1}$ are typical of the digital finger print of the cellulose backbone and could not be distinguished from pristine cellulose (Figure 1a, see also Figure $S 1$ in the Supporting Information for pristine cellulose). The integrity of disulfide functions can be verified by XPS through examination of the $S 2 p$ spectrum (Figure $1 b$, see also Figure S4 in the Supporting Information for pristine cellulose). The two spin orbit peaks observed at 164.8 and $163.6 \mathrm{eV}$ for S $2 \mathrm{p}_{1 / 2}$ and $S 2 p_{3 / 2}$, respectively, corresponding to a spin-orbit splitting 

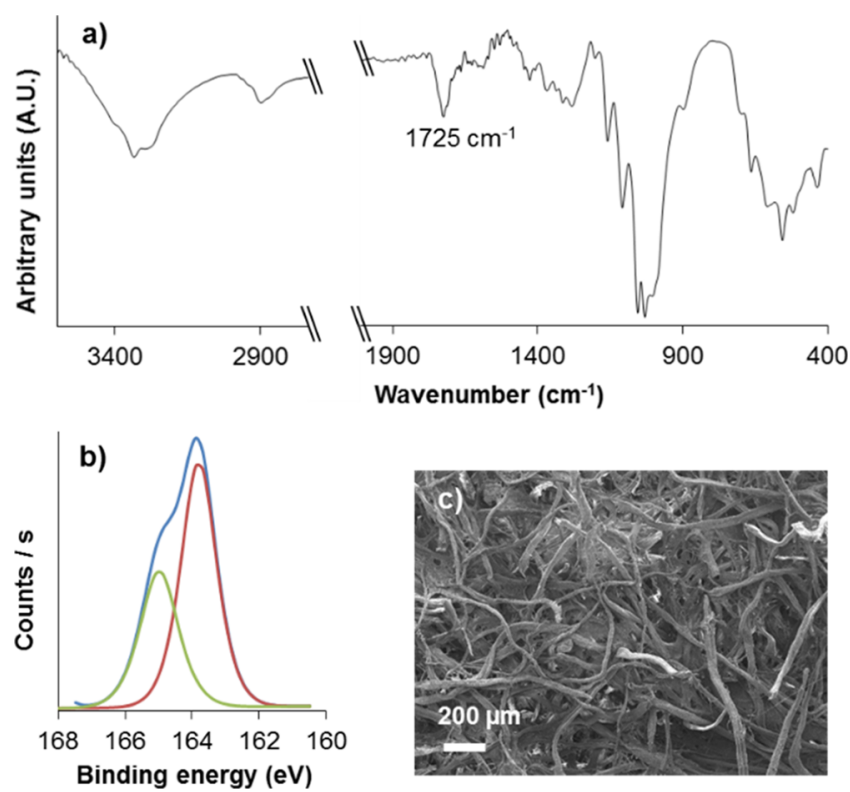

Figure 1. (a) FTIR spectrum, (b) high-resolution S 2p XPS spectrum, and (c) SEM image of Cell-DiS.

of $1.2 \mathrm{eV}$, are characteristic of disulfide functions. Last but not least, both the acidic conditions induced by the use of $\mathrm{BF}_{3}$. $\mathrm{Et}_{2} \mathrm{O}$, and the chemical grafting of dithiodiglycolic acid does not affect the morphology of the cellulose fibers, as evidenced by SEM analysis (Figure 1c, see also Figure S5 in the Supporting Information for pristine cellulose).

Having an optimized procedure to prepare Cell-DiS in reliable conditions, we then turned our attention to the challenging hydrophobic patterning of cellulose paper (Figure 2a). The experimental setup regarding the patterning consists of the use of Cell-DiS inserted in a sample holder consisting of two aluminum plates; the top plate is drilled on a diameter of 6 $\mathrm{mm}$ to draw a circular pattern on Cell-DiS. The sample holder is immersed in a solution containing the hydrophobic compound to be grafted and DMPA as radical initiator under light irradiation at $365 \mathrm{~nm}$. This experimental procedure was first optimized on a benchmark process involving the use of norbornene as a hydrophobic moiety through a photothiolene ligation. The success of the hydrophobic patterning was initially assessed through the measure of the water contact angle. The nature of the solvent proved to be crucial for the success of the patterning because traditional solvents used in free-radical chemistry gave unsatisfactory results. For instance, erratic results and irregular patterns were observed when the benchmark patterning was carried out in dimethyl sulfoxide, whereas the use of $\mathrm{CH}_{3} \mathrm{CN}$ as a solvent did not generate any pattern onto the surface of Cell-DiS. In this framework, we discovered that ethyl hexanoate, an innocuous solvent widely used as olfactory compound in fragrance and food, was very effective to pattern Cell-DiS with norbornene, giving rise CellNorb with an excellent water contact angle of $125.3 \pm 1.4^{\circ}$ (see an image of a water droplet in Figure 2b). A detailed literature survey revealed that the use of ethyl hexanoate is unprecedented for conducting thiol-X reactions, and our results suggested that it could be a powerful solvent surrogate in free-radical chemistry. To diversify the chemical nature of the hydrophobic pattern, we also evaluated the photothiol-yne ligation of the cholesterol derivative 3 . We measured an outstanding water contact angle of $140.8 \pm 1.1^{\circ}$ for the corresponding material Cell-Chol (see an image of a water droplet in Figure 2c). We stress that both pristine paper and Cell-DiS instantaneously absorbed water droplets and displayed a water contact angle of $0^{\circ}$. Upon immersion of Cell-Chol in water, the circular pattern was revealed in deep white, whereas the nonpatterned area was slightly stained by the moisture (see picture in Figure 2c). A droplet of water deposited onto the hydrophobic area permanently remained at the surface, in the limit of its evaporation (ca. $1 \mathrm{~h}$ at $25{ }^{\circ} \mathrm{C}$ ), whereas the nonpatterned area retained the native hydrophilicity of pristine cellulose paper.

Surface characterization of both Cell-Norb and Cell-Chol through XPS shows a sharp increase of the $\mathrm{C}\left(\mathrm{sp}^{3}\right)$ component of the C 1s spectra with respect to Cell-DiS (Figure $2 \mathrm{~d}-\mathrm{f}$ ). By contrast, the huge contribution of vibration modes from the cellulose backbone precludes any accurate analysis of the grafting process by FTIR because the digital fingerprints of
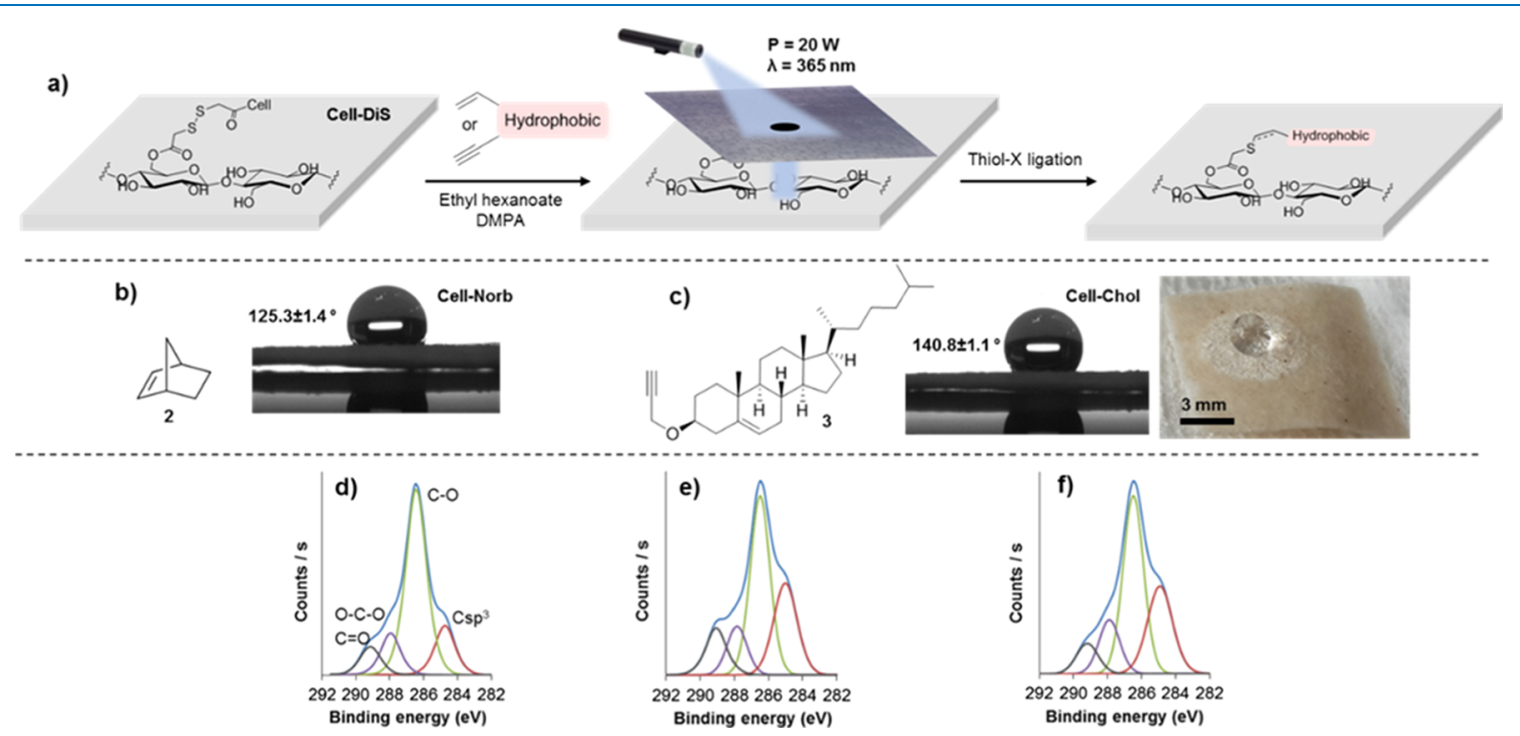

Figure 2. (a) General strategy for the hydrophobic patterning of Cell-DiS. (b,c) Hydrophobic moieties evaluated through the photothiol-X strategy with images of water droplets. High resolution of C 1s spectra of (d) Cell-DiS, (e) Cell-Norb, and (f) Cell-Chol. 
both Cell-Norb and Cell-Chol were not discernible from that of Cell-DiS (Figures S2-S3, see the Supporting Information). The only, but not less important, information extracted from the FTIR spectra is related to the carbonyl band intensity which was not modified, confirming that the ester linkage was not damaged by the photothiol-X ligation. The very regular shape of the pattern associated to its high hydrophobicity validate the photothiol-X strategy as a very competitive technology for producing robust spatially controlled hydrophobic area onto the surface of cellulose paper in a straightforward way and without any specific equipment such as a plasma reactor or dedicated printer.

\section{EXPERIMENTAL SECTION}

General Remarks. Contact angle measurements were performed on a drop shape analyzer of Kruss. The resolution of the camera charge-coupled device is $1024 \times 768$ pixels; the volume of the water drop is $1.0 \mu \mathrm{L}$; and the diameter of the needle is $0.514 \mathrm{~mm}$.

General Procedure for the Pretreatment of Cellulose Paper. One piece of commercially available cellulose filter paper was mercerized following our previously reported procedure. $^{39}$

Synthesis of Dithiodiglycolic Acid (1). Dithiodiglycolic acid 1 was prepared, following our recently described procedure. $^{39}$

Preparation of Cell-DiS. A piece of mercerized cellulose paper (approx. $140 \mathrm{mg}, 0.86 \mathrm{mmol}$ ) in dry toluene $(40 \mathrm{~mL}$ ) was treated with a solution of $\mathrm{BF}_{3} \cdot \mathrm{Et}_{2} \mathrm{O}(11 \mu \mathrm{L}, 0.086 \mathrm{mmol})$ in toluene $(11 \mathrm{~mL})$, and the resulting mixture was stirred for 5 min. Freshly prepared dithiodiglycolic acid (3 equiv per glucose unit) was added in one portion, and the mixture was stirred for $24 \mathrm{~h}$ at $110{ }^{\circ} \mathrm{C}$ under nitrogen atmosphere, protected from light. Cell-DiS was washed with $\mathrm{EtOH}$, $\mathrm{MeOH}$, acetone, and dichloromethane (DCM) under sonication, dried, and stored in the dark under nitrogen.

Synthesis of 3-(Prop-2-yn-1-yloxy)cholester (3). Cholesterol derivative 3 was prepared following our recently published procedure. ${ }^{40}$

Preparation of Cell-Norb. A mixture of norbornene 2 (100 $\mathrm{mg}, 1.062 \mathrm{mmol})$ and DMPA (40 mg, $0.16 \mathrm{mmol})$ in ethyl hexanoate $(6 \mathrm{~mL})$ was added in a glasstank. Then, $12 \mathrm{mg}$ of Cell-DiS was wedged between one photomask and an aluminum plate $(2 \times 2.5 \mathrm{~cm})$, immersed in the solution and irradiated with a UV light $\left(\lambda_{\max }=365 \mathrm{~nm}\right)$ during $150 \mathrm{~min}$ with vigorous stirring. Finally, Cell-Norb was sequentially washed with $\mathrm{EtOH}, \mathrm{MeOH}$, acetone, and DCM under sonication, dried under vacuum, and stored under nitrogen.

Preparation of Cell-Chol. A mixture of 3-(prop-2-yn-1yloxy)cholesterol 3 (451 mg, $1.062 \mathrm{mmol}$ ) and DMPA (40 mg, $0.16 \mathrm{mmol})$ in ethyl hexanoate $(6 \mathrm{~mL})$ was added in a glass tank. Then, $12 \mathrm{mg}$ of Cell-DiS was wedged between one photomask and an aluminum plate $(2 \times 2.5 \mathrm{~cm})$, immersed in the solution and irradiated with a UV light $\left(\lambda_{\max }=365 \mathrm{~nm}\right)$ for $150 \mathrm{~min}$ with vigorous stirring. Finally, Cell-Chol was sequentially washed with $\mathrm{EtOH}, \mathrm{MeOH}$, acetone, and DCM under sonication, dried under vacuum, and stored under nitrogen.

\section{CONCLUSIONS}

In summary, we established a photoresponsive cellulose paper as a powerful molecular platform which can be functionalized by covalently grafted hydrophobic patterns. The light-mediated thiol-X ligation is the key technology of our approach as it allows to produce well-defined hydrophobic patterns in mild conditions. For instance, the ligation of cholesterol units through a thiol-yne reaction produces patterns of high hydrophobicity with an outstanding water contact angle of $140.8^{\circ}$. We believe that this established thiol-X technology has a great potential for the creation of robust microfluidic devices with spatially resolved hydrophobic area. Our team is currently working on the creation of complex microfluidic devices for offsite diagnosis.

\section{ASSOCIATED CONTENT}

\section{Supporting Information}

The Supporting Information is available free of charge on the ACS Publications website at DOI: 10.1021/acsomega. 8 b01317.

FTIR spectra of pristine cellulose paper, Cell-Norb, and Cell-Chol and XPS spectrum and SEM image of pristine cellulose paper (PDF)

\section{AUTHOR INFORMATION}

\section{Corresponding Author}

*E-mail: fx.felpin@univ-nantes.fr. Phone: +33-025-112-5422.

ORCID $\odot$

Erwan Le Grognec: 0000-0002-3351-7028

François-Xavier Felpin: 0000-0002-8851-246X

Notes

The authors declare no competing financial interest.

\section{ACKNOWLEDGMENTS}

Denis Loquet (University of Nantes), Francois-Xavier Lefevre (University of Nantes), Christine Labrugère (PLACAMAT, Bordeaux) are gratefully acknowledged for elemental, SEM, and XPS analyses, respectively. SEM analyses were carried out at the Institut des Matériaux Jean Rouxel. F.-X.F. is member of the Institut Universitaire de France.

\section{REFERENCES}

(1) Klemm, D.; Heublein, B.; Fink, H.-P.; Bohn, A. Cellulose: Fascinating Biopolymer and Sustainable Raw Material. Angew. Chem., Int. Ed. 2005, 44, 3358-3393.

(2) Isogai, A. Material science of cellulose; Tokyo University Press: Tokyo, 2001.

(3) Kim, J.-H.; Shim, B. S.; Kim, H. S.; Lee, Y.-J.; Min, S.-K.; Jang, D.; Abas, Z.; Kim, J. Review of nanocellulose for sustainable future materials. Int. J. Precis. Eng. Manuf-Green Technol. 2015, 2, 197-213.

(4) Habibi, Y. Key advances in the chemical modification of nanocelluloses. Chem. Soc. Rev. 2014, 43, 1519-1542.

(5) Kumar, R.; Sharma, R. K.; Singh, A. P. Cellulose based grafted biosorbents - Journey from lignocellulose biomass to toxic metal ions sorption applications - A review. J. Mol. Liq. 2017, 232, 62-93.

(6) Malmström, E.; Carlmark, A. Controlled grafting of cellulose fibres - an outlook beyond paper and cardboard. Polym. Chem. 2012, 3, 1702-1713.

(7) Luo, Y.; Huang, J. Surface modification of natural cellulose substances: toward functional materials and applications. Sci. China: Chem. 2014, 57, 1672-1682.

(8) Kong, L.; Wang, Q.; Xiong, S.; Wang, Y. Turning Low-Cost Filter Papers to Highly Efficient Membranes for Oil/Water Separation by Atomic-Layer-Deposition-Enabled Hydrophobization. Ind. Eng. Chem. Res. 2014, 53, 16516-16522. 
(9) Barona, D.; Amirfazli, A. Producing a superhydrophobic paper and altering its repellency through ink-jet printing. Lab Chip 2011, 11, 936-940.

(10) Li, J.; Wan, H.; Ye, Y.; Zhou, H.; Chen, J. One-step process to fabrication of transparent superhydrophobic SiO2 paper. Appl. Surf. Sci. 2012, 261, 470-472.

(11) Arbatan, T.; Zhang, L.; Fang, X.-Y.; Shen, W. Cellulose nanofibers as binder for fabrication of superhydrophobic paper. Chem. Eng. J. 2012, 210, 74-79.

(12) Hu, Z.; Zen, X.; Gong, J.; Deng, Y. Water resistance improvement of paper by superhydrophobic modification with microsized $\mathrm{CaCO} 3$ and fatty acid coating. Colloids Surf., A 2009, $351,65-70$.

(13) Zhang, M.; Wang, C.; Wang, S.; Shi, Y.; Li, J. Fabrication of coral-like superhydrophobic coating on filter paper for water-oil separation. Appl. Surf. Sci. 2012, 261, 764-769.

(14) Du, C.; Wang, J.; Chen, Z.; Chen, D. Durable superhydrophobic and superoleophilic filter paper for oil-water separation prepared by a colloidal deposition method. Appl. Surf. Sci. 2014, 313, 304-310.

(15) Werner, O.; Quan, C.; Turner, C.; Pettersson, B.; Wågberg, L. Properties of superhydrophobic paper treated with rapid expansion of supercritical CO2 containing a crystallizing wax. Cellulose 2010, 17, $187-198$.

(16) Huang, L.; Chen, K.; Lin, C.; Yang, R.; Gerhardt, R. A. Fabrication and characterization of superhydrophobic high opacity paper with titanium dioxide nanoparticles. J. Mater. Sci. 2011, 46, 2600-2605.

(17) Yang, H.; Deng, Y. Preparation and physical properties of superhydrophobic papers. J. Colloid Interface Sci. 2008, 325, 588-593.

(18) Hansson, S.; Östmark, E.; Carlmark, A.; Malmström, E. ARGET ATRP for Versatile Grafting of Cellulose Using Various Monomers. ACS Appl. Mater. Interfaces 2009, 1, 2651-2659.

(19) Carlsson, L.; Malmström, E.; Carlmark, A. Surface-initiated ring-opening metathesis polymerisation from cellulose fibres. Polym. Chem. 2012, 3, 727-733.

(20) Bongiovanni, R.; Marchi, S.; Zeno, E.; Pollicino, A.; Thomas, R. R. Water resistance improvement of filter paper by a UV-grafting modification with a fluoromonomer. Colloids Surf., A 2013, 418, 5259.

(21) Geissler, A.; Loyal, F.; Biesalski, M.; Zhang, K. Thermoresponsive superhydrophobic paper using nanostructured cellulose stearoyl ester. Cellulose 2014, 21, 357-366.

(22) Kostić, S.; Berg, J. K.; Casdorff, K.; Merk, V.; Burgert, I.; Cabane, E. A straightforward thiol-ene click reaction to modify lignocellulosic scaffolds in water. Green Chem. 2017, 19, 4017-4022.

(23) Sun, D.; Wang, W.; Yu, D. Preparation of fluorine-free water repellent finishing via thiol-ene click reaction on cotton fabrics. Mater. Lett. 2016, 185, 514-518.

(24) Chitnis, G.; Ziaie, B. Waterproof Active Paper via Laser Surface Micropatterning of Magnetic Nanoparticles. ACS Appl. Mater. Interfaces 2012, 4, 4435-4439.

(25) Martinez, A. W.; Phillips, S. T.; Whitesides, G. M.; Carrilho, E. Diagnostics for the Developing World: Microfluidic Paper-Based Analytical Devices. Anal. Chem. 2010, 82, 3-10.

(26) Deiss, F.; Matochko, W. L.; Govindasamy, N.; Lin, E. Y.; Derda, R. Flow-Through Synthesis on Teflon-Patterned Paper To Produce Peptide Arrays for Cell-Based Assays. Angew. Chem., Int. Ed. 2014, 53, 6374-6377.

(27) Carrilho, E.; Martinez, A. W.; Whitesides, G. M. Understanding Wax Printing: A Simple Micropatterning Process for Paper-Based Microfluidics. Anal. Chem. 2009, 81, 7091-7095.

(28) Bruzewicz, D. A.; Reches, M.; Whitesides, G. M. Low-Cost Printing of Poly(dimethylsiloxane) Barriers To Define Microchannels in Paper. Anal. Chem. 2008, 80, 3387-3392.

(29) Wang, J.; Monton, M. R. N.; Zhang, X.; Filipe, C. D. M.; Pelton, R.; Brennan, J. D. Hydrophobic sol-gel channel patterning strategies for paper-based microfluidics. Lab Chip 2014, 14, 691-695.
(30) Li, X.; Tian, J.; Nguyen, T.; Shen, W. Paper-Based Microfluidic Devices by Plasma Treatment. Anal. Chem. 2008, 80, 9131-9134.

(31) Martinez, A. W.; Phillips, S. T.; Butte, M. J.; Whitesides, G. M. Patterned Paper as a Platform for Inexpensive, Low-Volume, Portable Bioassays. Angew. Chem., Int. Ed. 2007, 46, 1318-1320.

(32) Dietrich, M.; Delaittre, G.; Blinco, J. P.; Inglis, A. J.; Bruns, M.; Barner-Kowollik, C. Photoclickable Surfaces for Profluorescent Covalent Polymer Coatings. Adv. Funct. Mater. 2012, 22, 304-312.

(33) Guo, J.; Fang, W.; Welle, A.; Feng, W.; Filpponen, I.; Rojas, O. J.; Levkin, P. A. Superhydrophobic and Slippery Lubricant-Infused Flexible Transparent Nanocellulose Films by Photoinduced Thiol-Ene Functionalization. ACS Appl. Mater. Interfaces 2016, 8, 34115-34122.

(34) Guo, J.; Filpponen, I.; Johansson, L.-S.; Heißler, S.; Li, L.; Levkin, P.; Rojas, O. J. Micro-patterns on nanocellulose films and paper by photo-induced thiol-yne click coupling: a facile method toward wetting with spatial resolution. Cellulose 2018, 25, 367-375.

(35) d'Halluin, M.; Rull-Barrull, J.; Le Grognec, E.; Jacquemin, D.; Felpin, F.-X. Writing and erasing hidden optical information on covalently modified cellulose paper. Chem. Commun. 2016, 52, 76727675.

(36) Rull-Barrull, J.; d'Halluin, M.; Le Grognec, E.; Felpin, F.-X. Chemically-modified cellulose paper as smart sensor device for colorimetric and optical detection of hydrogen sulfate in water. Chem. Commun. 2016, 52, 2525-2528.

(37) Rull-Barrull, J.; d'Halluin, M.; Le Grognec, E.; Felpin, F.-X. A paper-based biomimetic device for the reduction of $\mathrm{Cu}(\mathrm{ii})$ to $\mathrm{Cu}(\mathrm{i})$ application to the sensing of $\mathrm{Cu}(\mathrm{ii})$. Chem. Commun. 2016, 52, 65696572.

(38) Rull-Barrull, J.; d'Halluin, M.; Le Grognec, E.; Felpin, F.-X. Harnessing the Dual Properties of Thiol-Grafted Cellulose Paper for Click Reactions: A Powerful Reducing Agent and Adsorbent for $\mathrm{Cu}$. Angew. Chem., Int. Ed. 2016, 55, 13549-13552.

(39) Rull-Barrull, J.; d'Halluin, M.; Le Grognec, E.; Felpin, F.-X. Photoresponsive cellulose paper as a molecular printboard for covalent printing. J. Mater. Chem. C 2017, 5, 5154-5162.

(40) d'Halluin, M.; Rull-Barrull, J.; Bretel, G.; Labrugère, C.; Le Grognec, E.; Felpin, F.-X. Chemically Modified Cellulose Filter Paper for Heavy Metal Remediation in Water. ACS Sustainable Chem. Eng. 2017, 5, 1965-1973. 